\title{
Balance and fall in Elderly: a Public Health Concern
}

\author{
Lilian Felipe* \\ Fluminense Federal University- Rio de Janeiro, South America
}

Submission: February 02, 2016; Published: February 06, 2017

*Corresponding author: Lilian Felipe, Fluminense Federal University- Rio de Janeiro. Brazil, Coordinator of Speech Pathologist and Hearing Sciences, R. Dr. Silvio Henrique Braune, 22, Nova Friburgo - RJ, 28625-650, Brazil, South America, Email: lilianfelipe@id.uff.br

\section{Short Communication}

It is well known that the maintenance of balance during everyday activities needs the interaction, integration and coordination of proprioceptive, visual and vestibular systems with the central nervous system and also well recognized the balance problems among older people. Aging affects each sensory system in human body. Generally, people are used to complications associated with the aging of senses such as vision and hearing. Nevertheless, the vestibular system is a sensory system that progressively begins to lose function, and one of the leading contributing to balance problems with age increasing [13].

Balance disorders during this period of life signify an important public health problem, first four of the association between risk of fall and morbidity/mortality, besides the affects that can cause for social relations and everyday activities, reducing future mobility and quality of life. Diverse scientific efforts are devoted to determining the origins of falling in elderly. Because balance is a complex function, the underlying cause of dizziness varies widely. In the face of such prevalent reports emphasizing an overpowering prevalence of age related to balance impairment, the etiology of the balance disturb is frequently hard to determine. The cause is frequently multifactorial, from many different origins as neurologic, cardiovascular, visual, vestibular, psychological and medicationrelated problems [4].

The patient management should be adapted according to the etiology for each individual, including medical and rehabilitative ones as well as the use of prosthetic devices. Several studies found different prevalence percentages, but all agreed that the amount of people falling increases with each decade after age 65 years.

The quantity of balance disorders with a declining vestibular system is certain to reach near epidemic proportions. The demand remains as to whether the health community system will be prepared to successfully handle such an overwhelming number of balanced impaired subjects. An understanding of the effects of elderly versus the vestibular system is imperative if clinicians are to better manage elderly patients with balance disorders [5].

So important issues as the rehabilitation are promotion, with implementation of programs to improve the balance and reduce the risk of falls, and prevention through activities and exercises approach regarding the functional health of the elderly in the community. Progress in public health and communitybased interventions has been increasing with the appropriate programs [6]. Multilevel interventions should be evaluated with measurements suited to their settings, goals, and purpose for better life quality of population, especially elderly one.

\section{Reference}

1. Faraldo-García A, Santos-Pérez S, Crujeiras-Casais R, Labella-Caballero T, Soto-Varela A (2012) Influence of age and gender in the sensory analysis of balance control. Eur Arch Otorhinolaryngol 269(2): 673677.

2. Dros J, Maarsingh OR, Beem L, van der Horst HE, ter Riet G, et al. (2011) Impact of dizziness on everyday life in older primary care patients: a cross-sectional study. Health Qual Life Outcomes 9: 44.

3. Felipe L, Cunha LCM, Cunha FCM, Cintra MTG, Gonçalves DU (2008) Presbyvertigo as a cause of dizziness in elderly (original title: Presbivertigem como causa de tontura no idoso). Pro Fono 20(2): 99103.

4. Soto-Varela A, Faraldo-García A, Rossi-Izquierdo M, Lirola-Delgado A, Vaamonde-Sánchez-Andrade I, et al. (2015) Can we predict the risk of falls in elderly patients with instability? Auris Nasus Larynx 42(1): 8-14.

5. Alrwaily M, Whitney SL (2011) Vestibular rehabilitation of older adults with dizziness. Otolaryngol Clin North Am 44(2): 473-496.

6. Ekvall Hansson E, Magnusson M (2013) Vestibular asymmetry predicts falls among elderly patients with multi-sensory dizziness. BMC Geriatr 13: 77. 

CC (i) This work is licensed under Creative BY DOI:10.19080/GJ0.2017.03.555619
Your next submission with Juniper Publishers will reach you the below assets

- Quality Editorial service

- Swift Peer Review

- Reprints availability

- E-prints Service

- Manuscript Podcast for convenient understanding

- Global attainment for your research

- Manuscript accessibility in different formats

( Pdf, E-pub, Full Text, Audio)

- Unceasing customer service

Track the below URL for one-step submission https://juniperpublishers.com/online-submission.php 